\title{
Religion: Its Origins, Social Role and Sources of Variation
}

\author{
Richard Startup \\ Honorary Research Fellow, Swansea University, Swansea, UK \\ Email: r.startup@swansea.ac.uk
}

How to cite this paper: Startup, R. (2020) Religion: Its Origins, Social Role and Sources of Variation. Open Journal of Philosophy, 10, 346-367.

https://doi.org/10.4236/ojpp.2020.103023

Received: July 22, 2020

Accepted: August 22, 2020

Published: August 25, 2020

Copyright $\odot 2020$ by author(s) and Scientific Research Publishing Inc. This work is licensed under the Creative Commons Attribution International License (CC BY 4.0).

http://creativecommons.org/licenses/by/4.0/

\begin{abstract}
Religion emerged among early humans because both purposive and non-purposive explanations were being employed but understanding was lacking of their precise scope and limits. Given also a context of very limited human power, the resultant foregrounding of agency and purposive explanation expressed itself in religion's marked tendency towards anthropomorphism and its key role in legitimizing behaviour. The inevitability of death also structures the religious outlook; with ancestors sometimes assigned a role in relation to the living. Subjective elements such as the experience of dreams and the internalization of moral precepts also play their part. Two important sources of variation among religions concern the adoption of a dualist or non-dualist perspective, and whether or not the religion's early political experience is such as to generate a systematic doctrine subordinating politics to religion. The near ubiquity and endurance of religion are further illuminated by analysis of its functions and ideological role. Religion tends to be socially conservative but has the potential to be revolutionary.
\end{abstract}

\section{Keywords}

Origins of Religion, Religion and Politics, Dualist and Non-Dualist Perspectives, Need for Religion, Ubiquity of Religion

\section{Introduction}

The aim of this article is to illuminate the multifaceted phenomenon of religion, using a wide range of evidence and argument. Consideration is given to the origins of religion, its social role and some key sources of variation. As anthropological studies amply illustrate, religion and magic tend to permeate social life in pre-literate societies (Gosden, 2020). Magic is limited in its scope while religion possesses various aspects or dimensions: the practical and ritual, the experiential 
and emotional, the narrative or mythic, the ethical and legal, and the material (Smart, 1993: pp. 12-23). Despite there being an elaborate narrative or mythic dramatis personae-for instance, of gods and angels—-the only facticities which one "comes up against" are people acting in religious ways, or buildings, works of art, and other material creations. Religion is evidently strongly integrated and highly strategic in the social, including cooperative, life of a society through its role in regulating the widest range of behaviour.

A religion is built up cooperatively over many generations and there may be said to be a religious tradition. Although the approach is partial it has proved possible to utilize the notion of a belief system in respect of religion, given that various elements interconnect in complex ways. There is a certain "freedom of action" in the cooperative elaboration of the ideas overtime flowing from the fact that the constraints in terms of the facticities are indeed relatively limited. Religion may be said to meet human needs but in no sense is it a straightforward manifestation of them; people experience it as meaningful substantially as a result of acculturation (plainly, often from early childhood). Correlatively, it is often the case that those adults encountering a religion for the first time experience the whole, or at least some elements of it, as bizarre (consider, for instance, the doctrine of the Trinity within Christianity or the idea of original sin). Complexity derives also from the feature that it is simultaneously making several different types of contributions to the life of the society.

The first issue to be addressed is origins. As far as we can judge religion originates naturally with the passage from the animal to the fully human level, but clarification is needed as to why this should be so. Strikingly, although early humans achieved full conceptualization of the physical world, it appears that the outlook at that stage could not possibly have been a kind of simplified version of a modern secularised or humanistic one. There are, however, important differences between explaining how a particular institution may come into existence and explaining its persistence and relative stability once it does exist. So too, it is not just the ubiquity of religion that needs explaining but also its highly varied character; sources of variation need to be identified. An initial objective is to throw light on a prime source of religious belief and activity (Stark, 1990).

\section{Early Patterns of Human Understanding and Explanation}

Various tendencies are apparent in the development of religion and one main pattern is here initially tracked. There is a need to consider how humans conceptualise their situation and then to show how this combines with, and has implications for, issues of power and legitimacy.

The passage from the animal to the fully human level is marked by the capacity to use language and also theory of mind. These are critical in understanding human behaviour: they enable individual human beings to grasp the intentionality of others, while people as a whole are able fully to comprehend that their existence is within a world of objects (Startup, 2019: sections 4 and 5). On this ba- 
sis, it can be understood how early humans came to understand and explain aspects of their situation and environment. Conceptualization would necessarily consist of two primary strands which are clearly discernible in our thinking today. They arise because the significant environment of any one person consists 1) of the (purposive) actions of people, and 2) of the non-purposive environment. In this respect, the situation has remained unchanged since the emergence of Homo sapiens utilizing language and theory of mind. Under 1) the pattern of explanation involves purposive (or personal) causation, while under 2) it involves non-purposive (or non-personal) causation.

1) The actions of people

Employs concepts for understanding human behaviour focused on purposes and reasons.

Examples: "He is hanging around here in the hope of stealing something". "Don't complain. She'd like to get there by nightfall".

2) The non-purposive environment

Employs concepts for understanding which involve patterns and causes but does not involve reference to purposes and reasons.

Examples: "Blackberries are likely to be found here because they were plentiful in the same month last year". "It won't light because the tinder got wet".

Arising out of the conceptual bifurcation, people understand each other and each other's behaviour in two different ways. This is because non-purposive causation also has application to aspects of humans themselves. Consider, for instance, the universal phenomenon of aging and the physical and behavioural changes which tend to accompany it. In observing others we understand them to be children, elderly people and so on. However, we simultaneously understand who they are while understanding their purposes and those of others orienting towards them. The same person is an elderly lady and Queen Elizabeth II.

Humans explain things because it is useful or valuable for them to do so. The time dimension is typically involved because there is concern with completed action, action in train, or anticipated action. Examples of explanations coming into play after the event would be, under 1), when something is lost concluding that somebody has stolen it; under 2), noting that the countryside is drenched and concluding that it has rained recently. Of course, though people may seek explanation after the event, providing an accurate one may be difficult. For instance, an article lost may simply have been mislaid rather than stolen. Also, there are many situations hard to place within an explanatory context. Those coming upon the sphinx for the first time would find it hard to situate what is observed within any explanatory framework. Not infrequently, human purposive activities have unanticipated consequences, making it particularly hard to judge the appropriateness of each type of explanation, either separately or in combination.

A further relevant concept is that of power (related also to "strength") which plays a part in both types of explanation. In respect of the first type, it is correct 
to say that while purposes, intentions and so on may be manifested in behaviour, in and of themselves they are non-material: the exercise of human powers is needed so that empirically-defined objectives may be achieved. In the explanation of human activity this contribution of human powers is being acknowledged, either implicitly or explicitly. The powers may be physical or non-physical (as with memory) but the focus here is on the former. We recognize, for instance, that when a physical rescue is being undertaken a mother may lift her small child but not vice versa. Thus, in respect of explanation by reference to purposive causation, there is recognition of the contribution made by potentially variable powers, in this case that of physical strength. But in the case of the second type of explanation too there is typically at least implicit acknowledgement of the contribution of power. Consider for instance the difference between saying a man died because a tree collapsed and hit him on the head and saying he died because a leaf hit him on the head; people would readily accept the former explanation but not the latter.

One is now in a position to identify a key source of the ubiquitous phenomenon of religion. Supposing one asks: given the conceptual bifurcation, is there at the same time understanding of the precise scope and limits of application of each set of concepts? In respect of that early stage of human development the answer is negative; indeed the concepts may be expected to be to a degree scrambled. Even the Ancient Greeks, who considerably advanced scientific understanding, sometimes used a teleological type of explanation of a natural phenomenon as when they forwarded the idea that water "seeks out" the lowest point.

An important contribution to the lack of clarity in understanding the scope of purposive causation concerns animals. That type of explanation is certainly used in respect of animals (as when one says "the dog wants some meat") but specifying its precise limits is difficult because animals are not members of the language-using community. (Consider the question: Do animals steal from one another?) At the risk of being pedantic, it is worth spelling out that we are able to clarify these distinctions because of our greater conceptual resources and resources of knowledge (although in actuality many people might struggle to order their ideas on what is a difficult topic). The suggestion being made is that religion tends to arise in the early circumstances of mankind because explanation by reference to the strand involving reasons and purposes is being applied in contexts where we would expect to use the other type of explanation; alternatively, elements of the two types of explanation may be inextricably mixed. In a related way, it may also be asserted that the line of demarcation (where this is discernible) between the contexts of application of the two types of explanation could well differ as between two early social groups.

Even in contemporary society one can discern strong motivation for people to seek to go beyond non-purposive explanations, even where these are readily available. There are occurrences that are readily explicable but are unlikely, such as winning a lottery or experiencing a house fire. We may properly think of 
these as chance events but they can make such a difference to individual lives that strong feelings focus on them. For instance, suppose something adverse happens-such as personal injury-where a non-purposive explanation is readily available, people are still inclined to proceed to ask such questions as: why then? why me? They also pray to achieve favourable and avoid unfavourable outcomes.

\section{The Exercise of Power, Legitimacy}

As noted, considerations of power enter at least implicitly into both types of explanation. In this connection, the life of any one individual depends upon the power exercised by other human beings as well as that stemming from the natural (non-human) world. However, the power that manifestly belongs within the second type of explanation can be vastly greater than that entering into the first, since human physical powers are so slight relative to those of natural phenomena; yet humans depend upon those phenomena for their very survival. Hence there is a motive and therefore a tendency for them to try to understand natural phenomena using concepts associated with the purposive explanation and understanding of human behaviour. This is why religion tends to be anthropomorphising in the sense that concepts derivative from humans and their behaviour tend to be attributed more widely e.g. to gods and spirits. To take a familiar example, when rains follow a long period of drought it may be that this is explained by reference to a purposive agent answering the prayers of the population i.e. responding as might a human agent to pleading. Understood in this way humans appear to have a measure of (indirect) control since by prayer they can make a desired outcome more likely. Thus religion may feel empowering.

Furthermore, early humans would be unable to distinguish sources and types of power in the way with which we are familiar; there would be awareness of purposive agency but what would be unclear would be the nature and limits of agency. In this connection, it is revealing that we have come to use the term "power" both in the physical sciences and in human affairs while being substantially aware of the underlying conceptual differences. In science, power is defined as the ability to do work in the mechanical sense and could be used for instance in respect of a machine or a hydro-electric plant. In human affairs, it refers to the ability of one agent to get one or more other agents to comply with their wishes or instructions. There is also a usage where one refers to a human being's "powers" meaning their potentialities in terms of action; this rather bridges the two contexts since we understand a human being as able to do work in the mechanical sense as well as being able to influence others. We fully recognize that it might make sense for a subordinate to ask a favour or plead with someone exercising power, while recognising that this would be pointless in relation to an inanimate power source. The very fact that in modern languages this single term has crystallized out into these two different meanings and contexts bears witness to the fact that they were integrated at earlier times. The same goes 
for the two differing meanings of "law", the one-descriptive-concerning generalizations about the external world and the other-normative-concerned with how humans should conduct their affairs; the two contexts would have been conceptually merged, or at least much less sharply distinguished, in the remote past.

Although familiarity with human action itself is the source of the idea of agency, a priori there is no reason to believe that agency is lacking from (say) a waterfall or cloud; after all each of these may generate desirable or undesirable outcomes. In addition, it may be altogether unclear what the scope of the power of humans or groups of humans is or was (recall the story of King Canute). Humans encountering a structure such as Stonehenge for the first time might easily have been led to believe it to be a superhuman product. (Potentially, there is lack of clarity regarding the source or location of collective agency). Agency could indeed be felt to inhere in any particular object or in the world at large. Dennett (2006) calls the tendency to attribute agency more widely the "intentional stance" and it is argued that this may facilitate the making of predictions which shape lives, even facilitating survival (Pagel, 2012: pp. 140-141).

Very importantly, the exercise of power by humans over others typically comes to involve the idea that it is right or legitimate for them to do so. Significantly, this idea provides greater security for those exercising power: where legitimacy is lacking subordinated people could cease to comply, rebel or go elsewhere at any time. This applies at all levels. For instance, parents have power over their children but all parties are encouraged to believe that this is as it should be. Again, the king or ruler of a state exercises power but every effort is made to get his or her subjects to accept that that is right and proper, and thus transmute the ruler's power into authority; subjects are expected to display devotion and treason is defined as the ultimate offence. Now this pattern has deep implications for religion and its social role. Where power is attributed to a super-human agent legitimacy tends to go with it. Significantly too, the authority of earthly rulers and other subordinate figures with power is generally underpinned by the system of law and morality. So where the idea of the law or moral order is extended from human society to embrace the whole universe this may both legitimise the activies of super-human agents, and further strengthen the position of earthly authorities. On the other hand, everyone is also familiar with usurpation or illegitimate rule in an earthly context, so that idea too can translate to the cosmic level. Thus from the outset, the orientation to the greater power in the world is bound up with ideas of legitimacy and illegitimacy (the devil, for instance, forming part of a duality) (Atran, 2002).

\section{Religion and Social Organization, Magic}

In proceeding further, it is essential to relate religious expression to type of social organization and mode of production. The whole point is that religion meaningfully interprets the more mundane and temporal, but the latter changes 
through extended time. At the outset social groups were small with kinship as the main organizing principle. Smart (1993: pp. 299-300) summarizes the character of traditional African religion in these terms: "gods and spirits, those unseen forces which explain and affect human life, are thought of and related to in human terms". Such beliefs and practices, common among ancient foragers, are most often termed "animist" (Harari, 2014: pp. 60-61). People were religiously oriented but religion in the sense of an elaborated institution hardly existed.

Following what some have termed the Agricultural Revolution larger, more sedentary populations emerged; partly for security reasons more centralised social entities also made an appearance. Animism receded and one finds among farmers the practice of polytheism. As Harari (2014: p. 237) puts it, "Humans could appeal to these gods and the gods might, if they received devotions and sacrifices, deign to bring rain, victory and health". The Greek gods were often motivated in their actions by sexual desire. Evidently, these various gods have patterns of motivation similar to those of human agents. Furthermore, since, as noted above, animals are to a degree also understood as purposive agents, and given also their importance as a wild or domesticated food source (and their role in traction), they often figure prominently in religious iconography.

At a later point states and empires emerged within which political power was exercised downward from the centre. This was the setting within which monotheism gained ground against polytheism; demonstrating links between political organization and theology. With the coming of monotheism, however, major religions continued to exhibit the same anthropomorphizing tendency which they do to this day: the deity may be related to personally, expresses love, has power and knowledge. Regarding Christianity, the suggestion would be that far from God having created man in his own image, man has instead created the idea of God with qualities derived from man, with superlative addition, such as "all-powerful" and "all-knowing". Purposive agency is being attributed way beyond its originating sphere.

Given an anthropomorphizing tendency, it may be readily judged that the phenomenon can build up in its collective, repetitive, ritualistic and organizational form. A human ruler does not simply look for individual acts of obeisance; no, he or she wants occasions when people may act as examples to each other; again, he or she is more flattered when larger numbers act in concert in this way. Furthermore, a ruler is never sufficiently reassured by a single act of obeisance; greater assurance stems from the repetition of collective acts through extended time. In the same way, the deity's requirements of humans are typically defined in a way which involves extended repetition, as typically applies to prayer; there is a need to show continuing devotion. Given human imaginative powers, religions constitute imposing, even magnificent structures, but when one unpacks the detailed behaviour attributed to gods and expected of people in relation to them, the various elements get their sense from how people relate to each other, especially rulers in relation to the ruled. 
As is well-known sacrifice is a very common feature of religions-of anything from vegetable matter and goats to human beings. But this too recalls the way humans orient to very high status individuals - as when the Queen is given a bouquet. The sacrifice is of things which human beings themselves value. The Biblical story of Abraham and Isaac provides an extreme case: in effect Abraham is being required to exhibit his greatest loyalty to God by sacrificing what is of greatest value to him, his son. He is being required to exhibit the ultimate in terms of devotion to God. A connected underlying idea is that we human beings and the divine agent share ideas as to what is of value; that is a further anthropomorphizing aspect.

The phenomenon of magic, a subsidary pattern evident in many societies may be briefly situated. Magic may involve an attitudinal element, as where it is assumed humans have a sympathetic relationship with nature and the cosmos (Gosden, 2020). Perhaps most often, however, magic is to be distinguished from religion through the idea that the former is to be understood (simply) as a quasi-technology; a human agent acts in order to produce a particular effect but we judge there to be no causal connection. In the case of sympathetic magic, an action performed on a doll representing a human is believed in a parallel way to affect the actual human; thus a link of a meaningful type is felt to have causal efficacy (Thackeray, 2013). However, in the generality of situations where a desirable or undesirable outcome is thought to be producible or to have been produced there may be lack of clarity as to whether human agency is or is not involved: hence, given sufficient motivation, there is scope for the belief that humans can so act as to "cause" effects where we judge it to be impossible. Regarding the point that magic, it might be claimed, is only sometimes effective, it is relevant to say that we still accept the explanation that aspirin causes a headache to disappear despite the fact that this is not invariably the case. No doubt too in some instances where supposedly magical effects are produced in a person, psycho-somatic factors are involved.

\section{The Symbol and That Which Is Symbolised}

Given that it is an expression of the extensive imaginative powers of humans, religion tends to have a highly elaborated nature marked by symbolic and narrative elements (See, for instance, Startup and Harris, 1997: pp. 218-220). All the elements in the environment of significance may figure in it (sometimes presented in the form of composites or hybrids), with animals and plants, upon which human life so depends, understandably appearing frequently. Totemism, most often found among populations with economies based on hunting and gathering, mixed farming with hunting and gathering, or the raising of cattle, is a phenomenon drawing together religion and social organization. Within that system of belief humans have a mythical relationship with a spirit-being, most often an animal or plant. That entity or totem interacts with the group and serves as its emblem or symbol (Leach, 2013). 
In earlier times particularly, the distant past would have tended to be shrouded in obscurity; as always, the future is uncertain and gives rise to apprehension. Linking in with purposive agency there is development in a narrative or mythic dimension (Hühn et al., 2009). Thus early Christianity provides an account of the creation; it goes on to tell us that the original humans disobeyed God and were driven from paradise; God wished to save the human race and the people of Israel were chosen as His instruments for this; Christ on earth died for human sins and made available God's grace to the faithful; at the end of time God will come with saving power. Of central importance, this narrative situates and normatively guides present behaviour: the faithful are the church community and grace comes in particular through ritual participation in Christ through the Eucharist (Harris and Startup, 1999: ch. 6). Hence the narrative and ritualistic elements connect up within the emergent religious institution (Finnern, 2014).

Religion is highly symbolic in its character and it also seems possible that the way in which it is expressed and understood may involve confusion between the symbol and the entity symbolized. Disagreements between Protestants and Catholics regarding the doctrine of transubstantiation point in this direction, as does the way in which people relate to icons in eastern orthodox Christianity. In respect of religion, that which is called forth by words, images, architecture, music, and ceremony can hardly be deemed not to exist. (The confusion between symbol and that which is symbolised is also involved in sympathetic magic).

Thus religion exists at least partly because of the attempt to understand events in the world as meaningful and in the same sort of way as one understands the behaviour of people. To see the position even more clearly it is worth going back to the basic notion that humans cooperate using theory of mind. What this means is that each of us is constantly "going beyond" the externalities of someone's behaviour to grasp intentionality, motive and related aspects. Given this highly personal starting point, however, there is a more general tendency in human life to "go beyond" physical externalities to make events meaningful and provide explanation: this is a major source of religion. (The tendency being considered here may even have a bearing on the ubiquity of "conspiracy theories" in modern life).

\section{The Significance of Death for Religious Ideas and Practices}

A consideration of the origin and nature of religion is bound to refer to the human familiarity with death and realization of its inevitability. Importantly, it is not just the thought of one's own death which is troubling but also those of near ones and dear ones; also critical is the point that this could occur at any time. Not just this, but there is underlying fear of illness, potentially distressing in itself but which could also presage early demise. Other animals are similarly situated in an objective sense, but with the passage to the human level there is un- 
derstanding of the reality, which threatens to hang like a dark cloud over life. It is not uncommon for humans implicitly to feel that they are better placed than other animals but in this respect they are not. Added poignancy is provided by the fact that humans are to a high degree future-oriented and concerned with security; yet, ultimately, future-oriented action will be interrupted or frustrated.

There is little doubt that religious ideas and practices have taken the various forms they have as a way of coming to terms with this "dark cloud": the objective phenomena are subsumed within a wider interpretive and speculative framework. Given familiarity with Christianity, it is hard not to concur with Russell (1925: pp. 18-19): "If we were not afraid of death, I do not believe that the idea of immortality would ever have arisen". Yet this is to pluck a single idea from one religious context. It is essential to stress that religious ideas and practices take many forms, are highly integrated and perform several different functions; but as one element they typically interpret or situate these disturbing phenomena in ways which people find meaningful, perhaps particularly in an emotional sense. This is illustrated by the notion that good people will go to heaven and the bad to hell, which makes the cosmos seem fairer, while giving expression to the desire for retribution. Yet it is striking that these concepts recycle in exagerrated form earthly sources of pleasure and pain, as portrayed, for instance, in Dante's Inferno.

It is indeed also the case that in many preliterate and traditional societies people orient towards ancestors in a religiously and socially significant way; they are powerfully significant in the present, where they may be invoked, for instance, to secure or challenge rights or responsibilities asserted. (For discussion focused on the Trobriand Islanders, see Mosko, 2017). Thus religion may be said to mediate the relation between the living and the dead (Boyer, 2001a). In the Confucian tradition of China rituals to honour ancestors are very important and need to be performed in precise ways. When properly carried out, an individual can receive the aid and cooperation of deceased relatives. Misfortune may be taken as a sign of displeasure by the deceased, and indicate that the proper rituals have not been followed (For a study relating the position of ancestors and kinship organization, see Bloch, 1993).

\section{The Interpretation of Subjective Elements}

To understand fully the early religious outlook attention must also be given to subjective elements. Taking a modern perspective it is readily appreciated that experience does not consist solely of experience of the physical world. For instance, one is conscious of the content of one's own thoughts and of one's own dreams, both of which may or may not be conveyed to others. To orient to the physical world is not to grasp the whole of experience, which was as true for early human beings as it is for us. But what sense is to be made of such elements as dreams? A priori there is no way of understanding their significance or non-significance. However, since interconnections are often initially grasped 
through correlation, some significance is likely to be attributed to them. From a modern perspective, it is abundantly clear that there are meanings to be extracted from dreams, and it is not at all surprising that they have been taken, for instance, as indications or predictions/prophecies.

Freud is, of course, a writer known for his interpretation of dreams but he is suggestive on another point too. In his later work, Freud (1949 [1923], 1955 [1920]) proposes that the human psyche may be divided into three parts: id, ego and super-ego. The id is the completely unconscious, impulsive, portion of the psyche that operates on the "pleasure principle" and is the source of basic impulses and drives; it seeks immediate gratification. On the other hand, the super-ego is the moral component of the psyche, which has no regard to special circumstances when the morally right thing to do might not be best for a particular situation. The third element, the rational ego, is usually reflected most directly in a person's actions where it attempts to achieve balance between the impractical hedonism of the id and the impractical moralism of the super-ego. Particularly pertinent here is this last which is the internalization of finger-wagging parental figures: you shouldn't lie, you shouldn't steal etc.; “conscience" is a word often used for it.

Now the modern understanding of internalization was not available in earlier eras. An important suggestion is that the source of the prohibitions and finger-wagging may be judged to be, or interpreted as, external e.g. God. Where God is understood as the source of the moral order and one hears one's own conscience, that experience could be viewed as communication from God. Paul's conversion on the road to Damascus can perhaps be partly understood in these terms (involving God speaking to him). Again, where one can seemingly hear the voice-or advice-of (say) a dead parent, could not that be communication from the next world? Something "internal" may hence be conceptualised as "external". No doubt, in evaluating the significance of subjective experiences for religion account must also be taken of the widespread use of hallucinogens and other mind-altering substances (Vernon, 2019).

Dreams and private thoughts are significant in an additional and somewhat different way. Importantly, they establish that physicality does not exhaust what a human being is. This has a bearing upon how death is construed. Basically, the central observational experience of the death of another is that that person will never move again or never do anything in a publicly observable bodily sense; in addition, the body will generally decay. But the existence of private thoughts and dreams makes clear that one is not totally made up of bodily form and publicly observable actions: there is more. This leaves open the possibility that the subjective elements form the basis for persistence of the individual (or the "soul") beyond death (and, conceivably also, prior-existence before birth or even conception), so the widespread existence of beliefs of this type is only to be expected. The modern expectation that oblivion follows death (and precedes conception) is well-grounded, for instance on evidence demonstrating the interdependence 
of the mental and the physical, but this fuller understanding is essentially a product of science (Dawkins, 2006).

There are other religious topics where a modern secularized understanding will differ from that of early human beings. It has been noted that pre-literate peoples generally understand that there is a link between sexual intercourse and subsequent childbirth while interpreting it in their culturally variable ways; no doubt the underlying basis of the understanding is again correlational. However, do they understand as we do that birth cannot take place without prior sexual intercourse (i.e. in the absence of recently developed technologies)? There is no reason to think they would be confident on this point. Hence the notion that a virgin birth could take place, probably as a relatively exceptional or even special event, is one that could easily have currency. This type of belief can thus find a place within the religious type of outlook to be expected in the earlier circumstances of mankind.

\section{Cognitive Approaches}

Complementing the position taken so far-and seemingly with more direct links to evolutionary theory-are recently developed cognitive approaches which seek to illuminate the origins and varieties of religion. In this connection, it is relevant to note that evolutionary theory has greatly expanded since Darwin's day and is judged to bear effectively upon disciplines such as anthropology and psychology. As one would expect the key idea is that one can understand how we think through understanding the human mind as a product of evolution i.e. it developed as it did to facilitate the survival of the species. As is well-known, one can understand differences between male and female outlooks and behaviour in respect of sex in this kind of way.

Illustration of the relevance to religion is provided by reference to Boyer's "modularity of the mind" thesis, which hinges on the idea that the human mind consists of various "modules" processing different types of information and giving rise to differing expectations and inferences about the world (Boyer, 2001a, 2001b). This leads to the idea that religion is the consequence of the functioning of differing domain-specific modules: beliefs about the supernatural originate from core knowledge being misapplied from one domain to another i.e. by a kind of cognitive malfunction. These concepts "excite" the mind and propagate readily because they have the power to generate many inferences (Boyer, 2001a: p. 164). However, Bloch is unconvinced partly on the grounds that our core knowledge is shared with other animals which, nevertheless, manifest nothing resembling religion in their behaviour. (The view taken here differs in the respect that human but not animal knowledge is based upon full conceptualisation of the external world). Bloch (2008: p. 2060) reckons that religion arises out of, and gives expression to, humans' imaginative powers. From the perspective developed here a further comment would be that Boyer focuses on cognition but religion is also an associational phenomenon and religious orientation combines attitudinal and cognitive elements. 
Again cognitive in its emphasis but also bearing upon issues as to how religion is expressed is Whitehouse's $(2000,2004)$ "modes of religiosity" thesis. This author draws from psychological theories of memory and views forms of religious experience as deriving from specific cognitive systems. A key distinction made is that between "semantic" memory and "episodic" memory, the former being concerned with abstract knowledge of the world, the latter concerned with actual occurrences in a person's experience (Whitehouse, 2000: p. 113). The suggestion is that the different forms of memory underpin different types of religious life. Whitehouse traces links between, on the one hand, semantic memory taken together with the relatively anonymous character of communities and, on the other, relatively unemotional and doctrinally-organised forms of religion. In addition, he points to links between episodic memory together with highly cohesive social ties and intense and imagistic forms of religion. Whitehouse judges that, while the modularity thesis bears upon universal features of religious thinking, his modes thesis accounts for religious variation. However, it has been suggested that there is no ready explanation for-what is frequently observed"oscillations between both modes within the same traditions" (Tremlett, 2013: p. 111).

Ingold's $(1996,2001)$ work has a different emphasis for it involves a move away from putative universal mental mechanisms back towards anthropological scrutiny of everyday life. Indeed he rejects the picture of the mind as involving fixed mental systems in favour of a developmental model. Our human capacities are attributable not so much to genetic inheritance but to what he refers to as a development system which is "the entire system of relations constituted by the presence of the organism in a particular environment" (Ingold, 2001: p. 261). Within "the environment" he appears to include both the natural world and culture and relationships. Clearly in some respects complementary to that of Boyer, his approach probably recalls for some the nature/nurture controversy, but though it feeds into the study of religion within particular societies, it remains to be demonstrated how it would contribute to understanding the origins of religion or its development as an institution.

\section{A Dualist or a Non-Dualist Outlook}

In a suggestive early work Frankfort and Frankfort (1961: pp. 11-13) characterize the outlook in Ancient Egypt and Mesopotamia as being of an "I-and-Thou" type. Significantly, three elements seem to be implied here: 1) both self and world are construed in terms of agency; 2) there is felt to be an intimate relationship between them; 3) "Thou" has greater power. Also, the orientation to the greater power in the world is bound up with ideas of legitimacy and illegitimacy.

Frankfort and Frankfort (1961) are focusing on near-eastern peoples. Thinking more generally, there seem to arise two main alternatives in terms of orientation in respect of power. Considering matters objectively, one would say that although an individual or local human group evidently has some power, the 
power located elsewhere in the world is-almost literally-infinitely greater, as demonstrated by such natural phenomena as the Sun rising and setting; or, in a modern context, through our understanding that life on Earth is dependent upon there being a continuous supply of energy from the Sun. Therefore the perspective may be that the individual (or local group) is set over and against massive power; but there is an alternative. There is also the possibility that power may be felt to inhere in the massive totality of the world but that the individual (or group) is understood to partake in it or draw from it temporarily. (The underlying logical distinction is between identifying this as distinct from that, as against identifying this as part of that.) The former of this pair of conceptualizations seems to feed into the dualist perspective characteristic of western peoples while the latter fits more into the non-dualist (or monist) outlook often found in the orient (Wilkinson, 2003). An illustration of the latter is the key idea within Hinduism of Dharma, "[t]he pattern underlying the cosmos and manifest in the ethical and social laws of humankind" (Smart, 1993: p. 85). Significantly, this concept seeks simultaneously to grasp the non-purposive and purposive spheres.

Importantly, too, the superhuman order governing the world may or may not be viewed as governed by the wills or purposes of gods. An alternative is for that realm to be understood as governed by natural laws just as is the everyday world of humans, animals and plants. This way of thinking partly arises from extension of the scope of application of non-purposive explanation. Included in this category of "natural-law religions" would be Buddhism, originating in India, and Confucianism and Taoism in China (Harari, 2014: p. 249). Within Buddhism the aim is liberation from suffering through experiencing reality as it is, without craving. Hence there are basic and essential differences between the major world religions perhaps epitomized by the suggestive contrast between saving souls on the one hand and loss of self on the other. In their origins, these modes of thinking and orienting are emphatically not to be considered as some kind of "mistake", rather they are consequences of the way in which conceptualization develops (Mithen, 1999; Wright, 2009).

As alluded to earlier, a further, rather different type of duality is central to the rationale of several religions which, though prominent once, have experienced marked decline; these include Zoroastrianism, Gnosticism and Manichaeanism. This type of religion provides a response to the question: why is there both good and evil in the world? The answer given is that there are independent good and evil powers-good and evil gods-loose in the world. It could be argued that this idea is sufficiently convincing for it to have been substantially taken over by many supposed adherents of monotheism who explain outcomes in the world by reference to God and the Devil (or Satan).

\section{Religion and Politics: A Contrast between Christianity and Islam}

So in their differing ways religions are concerned with the orientation to power 
and ideas of legitimacy and illegitimacy within a society. Hence there are bound to be interconnections between religion and politics in empires and nation states, but there are striking differences in the way in which this works itself out. This may be illustrated through a contrast between Christianity and Islam.

It is an important fact regarding Christianity (key concept "love") that it first established itself among subordinated peoples in the Roman Empire; only in the fourth century CE did it become the religion of the whole empire under Constantine the Great. Important documents-such as the gospels-originate from the early period, as do certain doctrines and practices. Major figures such as Paul sought to convert officials and other high status people but they did not contest their authority in any direct sense. (Of course it would have been fatal to do so). The result is that Christianity does not contain a systematic doctrine subordinating politics to religion. The key New Testament quotation is of course: "Render unto Caesar the things that are Caesar's and render unto God the things that are God's". A consequence has been that in the Western tradition there has tended to be a relation of dynamic tension between Christianity and politics but the latter has been gradually able to establish its independence and develop in a secular direction.

It is an important fact regarding Islam (key concept "surrender" or "submission") that as it became established (in the seventh century CE) it became politically dominant in its associated territory and its range was then rapidly extended geographically. Hence there was absolutely no incentive for there to be sharp doctrinal distinction between the religious and the political spheres; far from it. In fact, one can say that religious advancement was from the outset partly defined in political terms. As Smart (1993: p. 282) puts it: "Morality for the early Muslim was thoroughly woven into the political task of founding a good and just society under the guidance of God".

Now, of course it was the case that at a later stage Muslim states tended to be dominated politically in various ways by European Christian powers but this did not change the underlying outlook on religion and politics. In fact Islam has virtually enshrined the idea that periodic reassertions throughout a society-at all levels-of the basics of that faith are needed in order to express its true Islamic nature. The Qur'an is the fundamental reference point and is understood to be God's eternal speech. Nor has Islam gone through any equivalent of the Reformation. The consequence is that even today a central position taken by many Muslims is that politics should be subordinate to Sharia (i.e. revealed law). Hence the stances of Christianity and Islam in respect of politics are contrasting.

\section{An Investment in Power and Advantages over Others}

It need hardly be said that, given the religious outlook, where it is felt that particular individuals or groups can release the more general or overarching power, or invoke it, or be understood to act in conjunction with it, this itself massively enhances their ability to achieve outcomes in the face of other human beings. In 
the modern world this is in fact one of the main ways in which religion is experienced. The non-believer does not feel that he or she has access to, nor is their life "overlooked" by, any such non-human agency. On the other hand, believers feel themselves to be acting in harmony with and even able to invoke massive power, also viewed as the source of legitimacy. Not infrequently believers feel they gain advantages or privileges against non-believers; not infrequently it is felt the "wrath" of cosmic powers could vent itself on non-believers or those adhering to other religions. The point being made is that religion itself is a source of power (quite irrespective of putative sources of power and legitimacy of supernatural origin), which is an underlying reason why people in the modern world are so reluctant to give it up (Wade, 2009): they have a considerable investment in it. A further feature contributes to the difficulty of giving up a religion: its ideas tend to be tightly integrated and constitute a "self-sealing system" which it is difficult to think one's way out of from the inside.

\section{The Functions of Religion}

It seems that fully to understand the phenomenon of religion there is a need to consider both cognitive and other capacities of individuals and the nature of cooperation and cooperative frameworks. It has been argued that religion evolved as one of the behavioural mechanisms designed to facilitate community bonding (as numbers came to exceed 150) (Dunbar, 2020). It may tend to create large groups and facilitate further population growth (Startup, 2014). Indeed, both the individual and the relational are brought to attention when consideration is given to the familiar question: do we need religion? Responses to this question are informed by approaches and contributions within social anthropology which have been characterised as "functionalist" or "structural-functionalist" in their character. Consideration of the so-called "functions" of religion is helpful so long as it is understood that it bears rather less on the issue of origins and rather more on the contribution to social integration and stability. The suggested functions (or consequences) of religion are sometimes for individuals and sometimes for society as a whole. For example, Malinowski (1948) says that religious ritual relieves anxiety when people are embarking upon a risky venture. On the other hand, it may be suggested that religious ritual draws people together; it integrates society. Evidence from social science suggests that societies held together by some kind of religious practice may survive more effectively or for longer. The notion here might be that among humans there is evolutionary adaptation to the use of shared rituals; they may indeed have tangible benefits. The imagining of invisible agents could play a role, for instance, in underpinning cooperative social behaviour. Religious sanctions have been prominent in systems of social control. Rather different but potentially pertinent too is Girard's theory that religion was necessary in human evolution to control the violence that can come from mimetic rivalry (Fleming, 2004).

Of course, there are important differences in relevant respects between simp- 
ler and more complex societies. A feature of modern societies is that they contain many ethnic and religious differences. Nevertheless some would probably say that a society like the UK is partly integrated, not so much by being Christian, but from the fact that it arises from a Christian civilization. With regard to the functions of religion for individuals this point arises: were it suggested religion relieves anxiety regarding (say) death it might be added that the construction of heaven, hell and day of judgment introduces new sources of anxiety which otherwise would not be there. Again, supposing it is agreed that religion may be integrative and increase group identities and loyalties, at the same time this may be interdependent with hostility between religious groups, as it has been for extended periods in Northern Ireland. A very important feature of major world religions has been the tendency for schism to occur e.g. within Christianity, between Roman Catholic and Protestant, and within Islam, especially between Sunni and Shia, but also involving smaller sects.

\section{Karl Marx: Religion Is an Aspect of Alienation and Is Ideological}

To understand the human situation Marx makes use of the notion of alienation. With respect to capitalism alienation involves such aspects as the worker losing control over the disposal of what he himself produces; more generally it would be subjection to so-called economic laws like that of supply and demand-which are not natural laws and not really laws at all but in fact flow from patterned human behaviour itself. Alienation implies loss of control. The failure to understand the source of this loss gives rise to religious interpretation. In the future in the unalienated condition of communism-more like an Israeli kibbutz than the former Soviet Union-the need for religion would disappear. Hence Marx's critique of the "vale of tears":

Religious suffering is, at one and the same time, the expression of real suffering and a protest against real suffering. Religion is the sigh of the oppressed creature, the heart of a heartless world and the soul of soulless conditions. It is the opium of the people ... To call on them to give up their illusions about their condition is to call on them to give up a condition that requires illusions. The criticism of religion is, therefore, in embryo, the criticism of that vale of tears of which religion is the halo (Marx, 2009 [1844]).

According to Marx, religion defers happiness and rewards to the after-life, teaching the resigned acceptance of existing conditions in this life. Attention is thus diverted away from inequalities and injustices in this world by the promise of what is to come in the next. Religion has a strong ideological element: religious beliefs and values often provide justifications for inequalities of wealth and power; consider, for instance, the contribution of the Dutch Reformed Church within apartheid South Africa. Also, the teaching that "the meek shall inherit the earth" may engender attitudes of humility and non-resistance to oppression. We would, however, surely want to say that religion can be both revolutionary and 
conservative; consider, for instance, the conflict in England in the mid-seventeenth century between supporters of the king and of parliament where both sides claimed religious inspiration.

Marx says the unsatisfactory nature of the human situation gives rise to religion. That unsatisfactory nature has many aspects including our vulnerability to natural forces and to each other (including economic forces); and the fact that we can be overtaken by illness and death at any time. Marx sees religion arising from our unsatisfactory condition but affirms that it does not lay bare and confront that unsatisfactory condition. That is partially correct but religion can to an extent address aspects of it, as is illustrated by Christianity's message of love: were we to love one another, we would become less vulnerable to each other. However, the revolutionary character of a religion must to an important extent be judged historically. The development of Christian institutions and the interpretation and reinterpretation of its doctrines and practices (as in the Reformation) have been at the heart of the development of Western civilization itself. Seen in that light, the religion's contribution may perhaps be characterised as revolutionary.

\section{Conclusion}

A primary source of religion lies in the fact that early humans employed explanation by reference to both purposive and non-purposive causation but the scope and limits of each were not understood. Since human powers are so slight relative to the power of natural phenomena on which humans depend, there is a motive and impetus for them to seek to understand the natural world using concepts (such as agency) associated with purposive causation; indeed this may feel empowering. Partly because purposive explanation, although alluding to patterned behaviour, tends towards particularism (in that it refers to purposes defined within a particular cultural setting), while non-purposive explanation tends towards universalism, there have been many religions but only one phenomenon we call science. The religions we are familiar with in the modern world may be thought of as the survivors from a much larger pool; they have survived because their doctrines are susceptible to reinterpretation in radically changed circumstances; indeed even in times of rapid social change (Harris and Startup, 1999: ch. 9). This does not mean that they continue to "fit" their respective societies; as traditional institutions they are typically struggling to "keep up" and stay "relevant".

The foregrounding of agency and purposive explanation bears upon the marked tendency towards anthropomorphism within religion. A notable feature of purely human contexts is the way in which the less powerful are expected to orient to the more powerful: typically they are expected not just to acknowledge the power difference but are also made to display their acceptance of its legitimacy. Hence humans typically acknowledge greater power in a religious context while understanding it as the source of justification for their own actions. This 
most often also supplies the crucial element of cosmic or transcendental legitimacy to the authority of the most powerful human individuals and groups (as with the Egyptian pharaoh): hence an important sense in which religion is conservative. Significantly, where the deity is understood to be everywhere (or have access to everywhere) and all-knowing this is more effective in connection with social control than is purely human sanction.

Two other basic features of the human situation serve to structure religion: the inevitability of death and experiences of a subjective type or of the non-material. A "dark cloud" permanently hovering over humanity, death and its inevitability are a primary focus of religious interpretation; the perennial struggle is to make these meaningful, sometimes even in ways purporting to "overcome" death. In a wider sense, religion mediates between the living and the dead, and, while doing so, legitimizes practices of the living. The continuity of the subjective and of memory contributes to such a notion as that of the soul. It is of the essence that humans are symbol-users: religion is highly symbolic and probably arises and is shaped at least in part by confusion between the symbol and that which is symbolized. Important too, as Freud points out, normative elements internalised within individuals e.g. as "conscience", may be "externalized" i.e. interpreted as communication from the deity or ancestors.

Through understanding the human mind as the product of evolution, cognitive approaches seek to illuminate the origins and varieties of religion. In this connection, Boyer considers beliefs about the supernatural originate from knowledge being misapplied from one cognitive domain to another. Yet this suggestion seems critically to downplay the contribution of human imaginative powers. In a further contribution, Whitehouse relates different forms of memory together with certain patterns in community or social ties to contrasting modes of religiosity-doctrinally organized or intense and imagistic. Insight is provided into a striking dichotomy evident in religious practice.

Two important sources of variation in religions have been identified. The first concerns the orientation in respect of power. One approach gives rise to the dualist perspective at the root of major western religions while the other generates a non-dualist outlook, which underlies prominent religions of the orient. A second major source of variation among religions arises from their differing originating contexts; it has application to the major dualist occidental religions. There is a contrast between a religion experiencing a prolonged early period of subordinacy and one experiencing early political dominance in respect of the likelihood of it generating a systematic doctrine subordinating politics to religion. A further significant point is that while religion tends to be socially conservative, it may have longer-term revolutionary potential.

In an appraisal of the human condition, it becomes almost harder to explain not the presence and/or centrality of religion, but secularization and the circumstances in which religion may be successfully challenged or marginalized. In a modern secular context, we are used to taking the contours of the external 
world as a neutral, factual "given" to which we may orient instrumentally. While the orientations of early humans include instrumentality as an element, the latter is embedded within a wider religiously- and magically-shaped worldview. For us, as Max Weber indicates, given the character of modernized, bureaucratic, secularized Western society, there has been a "disenchantment of the world". The task of understanding how that disenchantment came about proves to be as challenging as that of understanding the origins and significance of the previously enchanted state.

\section{Conflicts of Interest}

The author declares no conflicts of interest regarding the publication of this paper.

\section{References}

Atran, S. (2002). In Gods We Trust: The Evolutionary Landscape of Religion. New York: Oxford University Press.

Bloch, M. (1993). Placing the Dead: Tombs, Ancestral Villages and Kinship Organization in Madagascar. Long Grove, IL: Waveland Press Inc.

Bloch, M. (2008). Why Religion Is Nothing Special But Is Central. Philosophical Transactions of the Royal Society B: Biological Sciences, 363, 2055-2061. https://doi.org/10.1098/rstb.2008.0007

Boyer, P. (2001a). Religion Explained: The Evolutionary Origins of Religious Thought. New York: Basic Books.

Boyer, P. (2001b). Religion Explained: The Human Instincts that Fashion Gods, Spirits and Ancestors. London: Heinemann.

Dawkins, R. (2006). The God Delusion. London: Bantam Books.

Dennett, D. C. (2006). Breaking the Spell: Religion as a Natural Phenomenon. London: Allen Lane.

Dunbar, R. I. M. (2020). Religion, the Social Brain and the Mystical Stance. Archive for the Psychology of Religion, 42, 46-62. https://doi.org/10.1177/0084672419900547

Finnern, S. (2014). Narration in Religious Discourse: The Example of Christianity. In P. Hühn, J. Pier, W. Schmid, \& J. Schönert (Eds.), The Living Handbook of Narratology, Hamburg: Hamburg University.

http://www.lhn.uni-hamburg.de/article/narration-religious-discourse-example-christia nity

Fleming, C. (2004). René Girard: Violence and Mimesis. Cambridge: Polity.

Frankfort, H., \& Frankfort, H. A. (1961). Introduction. In H. Frankfort, H. A. Frankfort, J. A. Wilson, \& T. Jacobsen (Eds.), Before Philosophy(9-36). London: Penguin.

Freud, S. (1949 [1923]). The Ego and the Id. London: The Hogarth Press.

Freud, S. (1955 [1920]). Beyond the Pleasure Principle, Group Psychology and Other Works. London: The Hogarth Press.

Gosden, C. (2020). The History of Magic: From Alchemy to Witchcraft, from the Ice Age to the Present. New York: Viking.

Harari, Y. N. (2014). Sapiens: A Brief History of Humankind. London: Harvill Secker.

Harris, C., \& Startup, R. (1999). The Church in Wales: The Sociology of a Traditional In- 
stitution. Cardiff: University of Wales Press.

Hühn, P., Pier, J., Schmid, W., \& Schönert, J. (2009). Handbook of Narratology. Berlin: De Gruyter. https://doi.org/10.1515/9783110217445

Ingold, T. (1996). The Optimal Forager and Economic Man. In P. Descola, \& G. Pálsson (Eds.), Nature and Society: Anthropological Perspectives (Chapter 2). London and New York: Routledge.

Ingold, T. (2001). From Complementary to Obviation: On Dissolving the Boundaries between Social and Biological Anthropology, Archaeology, and Psychology. In S. Oyama, E. Griffiths, \& R. D. Gray (Eds.), Cycles of Contingency: Developmental Systems and Evolution (pp. 255-279). Cambridge, MA: MIT Press.

Leach, E. (2013). The Structural Study of Myth and Totemism. London: Routledge. https://doi.org/10.4324/9780203708538

Malinowski, B. (1948). Magic, Science and Religion and Other Essays. Glencoe, IL: The Free Press.

Marx, K. (2009 [1844]). Introduction in A Contribution to the Critique of Hegel's Philosophy of Right (Transcribed by A. Blunden and M. Carmody). https://www.marxists.org/archive/marx/works/1843/critique-hpr/intro.htm

Mithen, S. (1999). The Prehistory of the Mind: The Cognitive Origins of Art, Religion and Science. London: Thames \& Hudson.

Mosko, M. (2017). Ways of Baloma: Rethinking Magic and Kinship from the Trobriands. Chicago, IL: Hau Books (Malinowski Monograph Series).

Pagel, M. (2012). Wired for Culture: The Natural History of Human Cooperation. London: Allen Lane.

Russell, B. (1925). What I Believe. London: Kegan Paul, Trench, Trubner \& Co.

Smart, N. (1993). The World's Religions. Cambridge: University Press.

Stark, R. (1990). Micro Foundations of Religion: A Revised Theory. Sociological Theory, 17, 264-289. https://doi.org/10.1111/0735-2751.00080

Startup, R. (2014). The Cooperative Being: Humanity and the Selfish Gene. Swansea: Cronfa. https://cronfa.swan.ac.uk/Record/cronfa17960\#.U85lf7GGeic

Startup, R. (2019). Structuring a Philosophical Approach. Open Journal of Philosophy, 9, 452-469. https://doi.org/10.4236/ojpp.2019.94028

Startup, R., \& Harris, C. C. (1997). Elements of Religious Belief and Social Values among the Laity of the Church in Wales. Journal of Contemporary Religion, 12, 215-228. https://doi.org/10.1080/13537909708580801

Thackeray, J. F. (2013). The Principle of "Sympathetic Magic" in the Context of Hunting, Trance and Southern African Rock Art. The Digging Stick, 30, 1-4.

Tremlett, P.-F. (2013). Nineteenth-Century Questions, Twenty-First-Century Answers? A Critical Introduction to Cognitive Approaches to Religion. In P.-F. Tremlett (Ed.), Controversial Ideas: Science, Atheism, Minds, Persons (Chapter 3). Milton Keynes: The Open University.

Vernon, M. (2019). The Evolutionary Origins of Religion. London: Theos. https://www.theosthinktank.co.uk

Wade, N. (2009). The Faith Instinct: How Religion Evolved and Why It Endures. New York: Penguin Press.

Whitehouse, H. (2000). Arguments and Icons: Divergent Modes of Religiosity. Oxford: Oxford University Press.

Whitehouse, H. (2004). Modes of Religiosity: A Cognitive Theory of Religious Transmis- 
sion. Walnut Creek, CA: Altamira Press.

Wilkinson, R. (2003). East Is East and West Is West: On the Fundamentals of the European and Eastern World Views. In C. Chimisso (Ed.), Exploring European Identities (Chapter 6). Milton Keynes: The Open University.

Wright, R. (2009). The Evolution of God: The Origins of Our Beliefs. New York: Little Brown. 